\title{
GENDER AND PERFORMANCE IN ARABIC LANGUAGE LEARNING IN LAGOS
}

\author{
K. O. OLANIYAN-SHOBOWALE ${ }^{1}$ \\ Department of Language, Arts and Social Sciences Education, Faculty of Education, \\ Lagos State University, Ojo, Lagos \\ Tijani Akinola MOGAJI² \\ Department of Foreign Languages, Faculty of Arts, Lagos State University, Ojo, Lagos \\ ${ }^{1}$ solalaniyan_2004@yahoo.com* \\ 2mogajitijani@gmail.com
}

*Corresponding author

Manuscript received 8 May 2017

Manuscript accepted 19 June 2017

\begin{abstract}
This study focused on gender analysis of performance and enrolment for Arabic Language in a selected Arabic school in Lagos State. The study adopted the survey method for choosing the admitted students during the three years between 2014 and 2016. The purposive sampling technique was employed to select Daaru Da'wah wal Irshaad as a case study. The results revealed that the male Arabic students performed significantly better than the female students. Secondly, it indicated that the enrolment of males is far higher than that of females. The study concludes on the need to encourage the womenfolk to cultivate Arabic learning and sensitize them on the wealth of opportunity accruable from learning the language.
\end{abstract}

Keywords: Arabic language, gender, enrolment, performance, Arabic schools

\section{Introduction}

Arabic is a Central Semitic language, and classified alongside other Semitic languages such as Hebrew and Aramaic. It has the largest number of speakers amongst the Semitic languages. It is spoken by more than $\mathbf{2 8 0}$ million people as a first language and by 250 million more as a second language. Most native speakers of Arabic reside in the Middle East and North Africa (Mogaji, 2009, p. 161). The New Encyclopaedia Britannica regards the Arabic language as a Southern-Central Semitic language spoken in a large area including North Africa, most of the Arabian Peninsula and other parts of the Middle East. Arabic is the language of the Qur'an (or Koran the sacred book of Islam) (sic) and is the religious language of all Muslims (Mogaji, 2009). 
Arabic, Himyaritic (South Arabic), and Ethiopic belong to the southern group of the Semitic languages, of which Phoenician and Hebrew form the western, Aramaic the northern, and Accadian (Assyro-Babylonian) the eastern group (Hitti, 1972, p. 152; Mogaji, 2009, pp. 161-162). Arabic is a member of the Semitic language family, which is part of a wider Hamito-Semitic family, including also ancient Egyptian within that family; it belongs to the Southern-Semitic or SouthWest Semitic branch, which includes two further sub-groups: South Arabian (comprising ancient Sabaean, Minaean, Katabanian, Hadramitic, etc in Yaman and Southern Hadramawt and modern Mehri, Sh Khauri etc in Northern Hadramawt and the language of the Island of Sokotra (Gibb, Kramers, Levi-Provencal, Schacht, Stern, Lewis, Pellat, Dumont and Savory, 1986, pp. 561-562; Mogaji, 2009).

Hitti contends that Arabic is the best surviving representative of the original Semitic speech, despite the fact that its recorded literature is one of the youngest of the Semitic literatures (1972, p. 152; Mogaji, 2009, pp. 161-162). In addition, it is generally believed to be nearer than any of the rest to the original archetype, the "rsemitisch" (Nicholson, 1985, p. xiv).

Internationally, the significance of Arabic language and its role in communication, education, media, commerce, tourism, diplomacy, technology and sports etc. are widely reported (Oderinde, 2007). Globally, Arabic language functions as the lingua franca of the Arabico-Islamic world. It is the medium of transmission of Islam to all the nooks and crannies of the world.

Hence, it permeated the socio-cultural, economic, political, religious, diplomatic existence of Muslims irrespective of race, culture, educational qualification and socio-economic orientation. Consequently, the language functions as a major international language and medium of communication in all spectra of human relations and inter-relations.

In the south-western part of Nigeria and specifically in Lagos State, Arabic education remains a significant pillar of public and private learning. Thus, Arabic instruction takes place at three different levels, namely, formal and government owned schools, formal and privately owned Muslim schools, and traditional and privately owned Arabic schools.

This paper focuses on the later type of schools (traditional and privately owned). According to Adetona (2017, pp. 8-14), this type of schools "are not guided by any syllabus and the volume of knowledge possessed by the proprietor is what is imparted to the students". They are purposely established for the propagation of the Islamic faith and all sciences. And despite its non-recognition by the government, they continue to flourish in Lagos state and they produce hundreds of male and female graduates yearly.

\section{Review of Literature}

The educational research on gender and language learning is germane and researchers continue to offer insights into its development and fluorescence. Arguably, the research on gender differences originated in the west (Qian, 2015). In the 1920s, the relationship between gender differences and language learning 
captured the interest of anthropologists, psychologists and sociologists, who did considerable research on the subject.

In this regard, Burstall, (1975) reported that girls were more scattered in all language testing than boys, in his tracking study of 6,000 French children. In same vein, Boyle's (1987) survey of 490 Hong Kong students about their English learning revealed that girls' English proficiency test scores were significantly higher than boys by nearly ten folds. In the light of these studies, Li, (2005) concludes that woman is superior to man in learning a foreign language. Qian (2015) posits that the advantage which the female gender has on the male gender in language learning is hinged on the following factors:

i. Physical factors: Psychology studies indicated that the partial side of the brain hemisphere of men and women is quite different in the speed of development and level of specialisation. Women's left hemisphere on sexual partial side of sexual function develops earlier and stronger than men's; therefore, they are better than men in terms of language expression. In addition, the biological anatomy of women is far more advanced than that of men. Consequently, women's sound and pronunciation organs develop much earlier than men's. Hence, the female students are good at verbal, hearing and expressional skills. Thus, their verbal expressional ability and auditory perception are stronger than those of boys. He contends further that girls have the advantage of intelligence, which indicates that girls have reason to get higher scores than boys; and

ii. Gender differences in IQ: Intelligence is not a kind of simple ability but the combination of attention, observation, memory, and thinking ability Qian (2015).

\section{A Brief Note on Daaru Da'wah Arabic Institute}

Sheikh Mustapha Zuglul Sanusi is the founder of Daaru Da'wah wal Irshaad Arabic School. He was born on $18^{\text {th }}$ August 1937 in Ikirun, Osun State, Nigeria. He obtained his preparatory and primary Arabic education from the Qur'anic School of his father Muhammad Sanusi. Thereafter, at the age of 18, he proceeded to Markaz Ta'lim al'Arabiyy al-Islamiy, Agege, Lagos where he received his Intermediate stage in Arabic studies (Al-'Idaadiyah) between 1955 and 1959. Upon his graduation, he worked as a teacher in his Alma Mata after which he embarked on an educational voyage to Lebanon, Egypt, Syria, Palestine and Saudi Arabia. In 1965, he was appointed the Principal of the Markaz, and obtained his Diploma in 1967 from the institution.

In 1970, Sheikh Mustapha established Daaru Da'wah wal-Irshaad in Olohunsogo, Mushin, Lagos. The school began with the Primary (Al-Ibtidaaiyyah) and the Intermediate (Al-I'daadiyyah) stages. In 1981, it moved to its permanent site at Isolo, Lagos where the Secondary stage of learning (Al-Thanawiyyah) commenced.

The total population of the school as at the time of this study is 600 students, male (535), and female (65); and there are eight classes from Al-Tahdiiriy (Preparatory) to Al-Thanawiyah altogether. In the $4^{\text {th }}$ class (Rabiah Al-I'daadiy), there 
are a total of 70 students, 58 males and 12 females. The average performance of the female students is $40 \%$, while it is $60 \%$ for the male.

\section{Methodology}

This study is a survey research which employed the purposive sampling technique to select Daaru Da'wah wal- Irshaad Arabic Institute, among notable Arabic Institutes in Lagos State. The study provided answers to the following research questions:

i. What is the enrolment ratio of the female and male students of Daaru Da'wah Arabic institute between 2014 and 2016?

ii. What is the mean achievement of the male and female students of Daaru Da'wah Arabic Institute in Arabic language between 2014 and 2016?

Against these research questions, 2 null hypotheses were also tested thus:

i. There are no gender-based significant differences in the enrolment for Arabic studies at the DDI between 2014 and 2016.

ii. There are no gender-based significant difference in the academic achievement at the DDI between 2014 and 2016.

Having obtained with necessary permission, primary data were collected from the institution management which comprised the number of students admitted between 2014 and 2016. Similarly, the academic performance of the same students was also collected for analysis. Frequency counts and t-test statistical tools were used to analyse data collected.

\section{Results and Discussion}

Table 1

Students' enrolment and students' sex cross tabulation (2014) count

\begin{tabular}{cccc}
\hline Students' Enrolment & \multicolumn{2}{c}{ Grouping Variables } & \multirow{2}{*}{ Total } \\
\cline { 2 - 3 } & Male & Female & \\
\hline Tahdiriy & 45 & 10 & 55 \\
Awwal I'daadiy & 80 & 10 & 90 \\
Thanni I'daadiy & 89 & 11 & 100 \\
Thaalith I'daadiy & 90 & 10 & 100 \\
Rabi'ah I'daadiy & 80 & 10 & 90 \\
Awwal Thanawiy & 81 & 9 & 90 \\
Thanni Thanawiy & 81 & 9 & 90 \\
Thaalith Thanawiy & 81 & 9 & 90 \\
\hline Total & 627 & 78 & 705 \\
\hline
\end{tabular}

(Source: Field Survey, 2014)

Table 1 shows the sex distribution of each class in 2014. This indicates that Thanniy and Thaalith I'daadiy are the most populated classes with 100 students. In addition, it indicates that the male students are the majority (627). There were only78 female students out of 705 students. 
Table 2

Students' enrolment and students' sex cross tabulation (2015) count

\begin{tabular}{cccc}
\hline Students' Enrolment & \multicolumn{2}{c}{ Grouping Variables } & \multirow{2}{*}{ Total } \\
\cline { 2 - 3 } & Male & Female & \\
\hline Tahdiriy & 46 & 9 & 55 \\
Awwal I'daadiy & 85 & 15 & 100 \\
Thanni I'daadiy & 91 & 9 & 100 \\
Thaalith I'daadiy & 85 & 15 & 100 \\
Rabi'ah I'daadiy & 79 & 11 & 90 \\
Awwal Thanawiy & 77 & 8 & 85 \\
Thanni Thanawiy & 77 & 8 & 85 \\
Thaalith Thanawiy & 77 & 8 & 85 \\
\hline Total & 617 & 83 & 700 \\
\hline
\end{tabular}

(Source: Field survey, 2015)

Table 2 shows the sex distribution of each class in 2015. This indicates that Awwal I'daadiy, Thanni I'daadiy and Thanni I'daadiy are the most populated class with 100 students. Furthermore, it implies that, the male students are the majority (617) and there were only 83 females out of 700 students.

Table 3

Students' enrolment and students' sex cross tabulation (2016) count

\begin{tabular}{cccc}
\hline Students' Enrolment & \multicolumn{2}{c}{ Grouping Variables } & Total \\
\cline { 2 - 3 } & Male & Female & \\
\hline Tahdiriy & 53 & 12 & 65 \\
Awwal I'daadiy & 81 & 19 & 100 \\
Thanni I'daadiy & 80 & 20 & 100 \\
Thaalith I'daadiy & 87 & 8 & 95 \\
Rabi'ah I'daadiy & 85 & 10 & 95 \\
Awwal Thanawiy & 78 & 7 & 85 \\
Thanni Thanawiy & 72 & 8 & 80 \\
Thaalith Thanawiy & 72 & 8 & 80 \\
\hline Total & 608 & 92 & 700 \\
\hline
\end{tabular}

(Source: Field Survey, 2016)

Table 3 shows the sex distribution of students in 2016. This indicates that Awwal I'daadiy and Thanni I'daadiy are the most populated class with 100 students. It indicates further that, the males are the majority (608), while there were only 92 females.

\section{Hypothesis One}

$\mathrm{H}_{0}$ : There is no significant difference between the enrolment for Arabic Studies among male and female students of Daaru Da'wah Wal-Irshaad Arabic Institute, Isolo, Lagos. 
$\mathrm{H}_{\mathrm{i}}$ : There is a significant difference between the enrolment for Arabic Studies among male and female students of Daaru Da'wah Wal-Irshaad Arabic Institute, Isolo, Lagos.

\section{4 enrolment.}

Table 4

$t$-test on enrolment of male and female students

\begin{tabular}{ccccc}
\hline Grouping Variables & $\mathbf{N}$ & Mean & $\begin{array}{c}\text { Std. } \\
\text { Deviation }\end{array}$ & $\begin{array}{c}\text { Std. Error } \\
\text { Mean }\end{array}$ \\
\hline Male & 627 & 271.50 & 153.410 & 5.614 \\
Female & 78 & 39.40 & 21.083 & 2.433 \\
\hline
\end{tabular}

Table 4 shows that the male students are more with higher mean of 271.50 than the females with a lower mean of 39.40 . The significance of the experimental group performance is tested and presented in Table 5 .

Table 5

t-test for hypothesis One

\begin{tabular}{|c|c|c|c|c|c|c|c|}
\hline & \multicolumn{7}{|c|}{ t-test for Equality of Means } \\
\hline & \multirow[t]{2}{*}{$\mathbf{t}$} & \multirow[t]{2}{*}{ df } & \multirow[t]{2}{*}{$\begin{array}{l}\text { Sig. (2- } \\
\text { tailed) }\end{array}$} & \multirow[t]{2}{*}{$\begin{array}{l}\text { Mean } \\
\text { Diffe- } \\
\text { rence }\end{array}$} & \multirow{2}{*}{$\begin{array}{l}\text { Std. } \\
\text { Error } \\
\text { Diffe- } \\
\text { rence }\end{array}$} & \multicolumn{2}{|c|}{$\begin{array}{l}\text { 95\% Confidence } \\
\text { Interval of the } \\
\text { Difference }\end{array}$} \\
\hline & & & & & & Lower & Upper \\
\hline $\begin{array}{l}\text { Students' } \\
\text { Enrolment }\end{array}$ & & & & & & & \\
\hline $\begin{array}{l}\text { Equal variance } \\
\text { assumed }\end{array}$ & 11.569 & 703 & .000 & $\begin{array}{c}232.1 \\
00\end{array}$ & $\begin{array}{c}15.30 \\
7\end{array}$ & 189.814 & 258.186 \\
\hline
\end{tabular}

Assumption $=$ Equal variances assumed

T- Test Calculated (Statistic) $=12.869$

Degree of freedom $=703$

Level of significance $=0.05$

Returned $p$-value $=0.000$

The $t$-test statistics was calculated as 11.569 , at 0.05 significance level, with 703 degrees of freedom, the returned $p$-value of 0.000 was found less than the level of significance $(p<0.05)$. There is a significant difference between the enrolment for Arabic Studies among male and female students of Daaru Da'wah Wal-Irshaad Arabic Institute, Isolo, Lagos. This indicates that the male students who enroll for Arabic Studies in 2014 are more than the females. 


\section{5 enrolment.}

Table 6

t-test on enrolment of male and female students in 2015

\begin{tabular}{ccccc}
\hline Grouping Variables & $\mathbf{N}$ & Mean & $\begin{array}{c}\text { Std. } \\
\text { Deviation }\end{array}$ & $\begin{array}{c}\text { Std. Error } \\
\text { Mean }\end{array}$ \\
\hline Students' Enrolment & & & & \\
Male & 617 & 281.50 & 151.410 & 6.614 \\
Female & 83 & 41.30 & 21.083 & 2.533 \\
\hline
\end{tabular}

Table 6 shows that the males are more with higher mean of 281.50 than the females with a lower mean of 41.30 .

Table 7

t-test for hypothesis One

\begin{tabular}{|c|c|c|c|c|c|c|c|}
\hline & \multicolumn{7}{|c|}{ t-test for Equality of Means } \\
\hline & \multirow[t]{2}{*}{$\mathbf{t}$} & \multirow[t]{2}{*}{ df } & \multirow[t]{2}{*}{$\begin{array}{l}\text { Sig. (2- } \\
\text { tailed) }\end{array}$} & \multirow[t]{2}{*}{$\begin{array}{l}\text { Mean } \\
\text { Diffe- } \\
\text { rence }\end{array}$} & \multirow{2}{*}{$\begin{array}{l}\text { Std. } \\
\text { Error } \\
\text { Diffe- } \\
\text { rence }\end{array}$} & \multicolumn{2}{|c|}{$\begin{array}{c}\text { 95\% Confidence } \\
\text { Interval of the } \\
\text { Difference }\end{array}$} \\
\hline & & & & & & Lower & Upper \\
\hline $\begin{array}{l}\text { Students' } \\
\text { Enrolment }\end{array}$ & & & & & & & \\
\hline $\begin{array}{l}\text { Equal variance } \\
\text { assumed }\end{array}$ & 14.669 & 698 & .000 & $\begin{array}{c}240.2 \\
00\end{array}$ & $\begin{array}{c}19.40 \\
7\end{array}$ & 179.814 & 268.171 \\
\hline
\end{tabular}

Assumptions $=$ Equal variances assumed

T-Test Calculated (Statistic) $=12.869$

Degree of freedom $=698$

Level of significance $=0.05$

Returned $p$-value $=0.000$

The $t$-test statistics was calculated as 14.669 , at 0.05 significance level, with 698 degrees of freedom, the returned $p$-value of 0.000 was found less than the level of significance $(p<0.05)$. There is a significant difference between the enrolment for Arabic Studies among the male and female students of Daaru Da'wah wal-Irshaad Arabic Institute, Isolo, Lagos. This indicates that the male students who enroll for Arabic Studies are more than the females. 


\section{6 enrolment.}

Table 8

t-test on enrolment of male and female students

\begin{tabular}{ccccc}
\hline Grouping Variables & $\mathbf{N}$ & Mean & $\begin{array}{c}\text { Std. } \\
\text { Deviation }\end{array}$ & $\begin{array}{c}\text { Std. Error } \\
\text { Mean }\end{array}$ \\
\hline $\begin{array}{c}\text { Students' Enrolment } \\
\text { Male }\end{array}$ & 608 & 241.10 & 131.110 & 5.114 \\
Female & 92 & 43.70 & 20.183 & 2.103 \\
\hline
\end{tabular}

Table 8 shows that the male students are more with higher mean of 241.10 than the females with a lower mean of 43.70 . The significance of the experimental group performance is tested and presented next.

\section{Hypothesis Two}

$\mathbf{H}_{\mathbf{0 2}}$ : There is no significant difference between the academic performance of the male and female students of Daaru Da'wah Arabic Institute, Isolo, Lagos in Arabic studies.

\section{4 academic performance.}

Table 9

t-test on performance of male and female students

\begin{tabular}{ccccc}
\hline Grouping Variables & $\mathbf{N}$ & Mean & $\begin{array}{c}\text { Std. } \\
\text { Deviation }\end{array}$ & $\begin{array}{c}\text { Std. Error } \\
\text { Mean }\end{array}$ \\
\hline Students' Performance & & & & \\
Male & 627 & 9.31 & 14.211 & .697 \\
Female & 78 & 4.52 & .503 & .058 \\
\hline
\end{tabular}

Table 9 shows that the male students performed better with higher mean score of 9.31 in the Arabic Institute than the females with a lower mean score of 4.52 .

Table 10

t-test for hypothesis Two

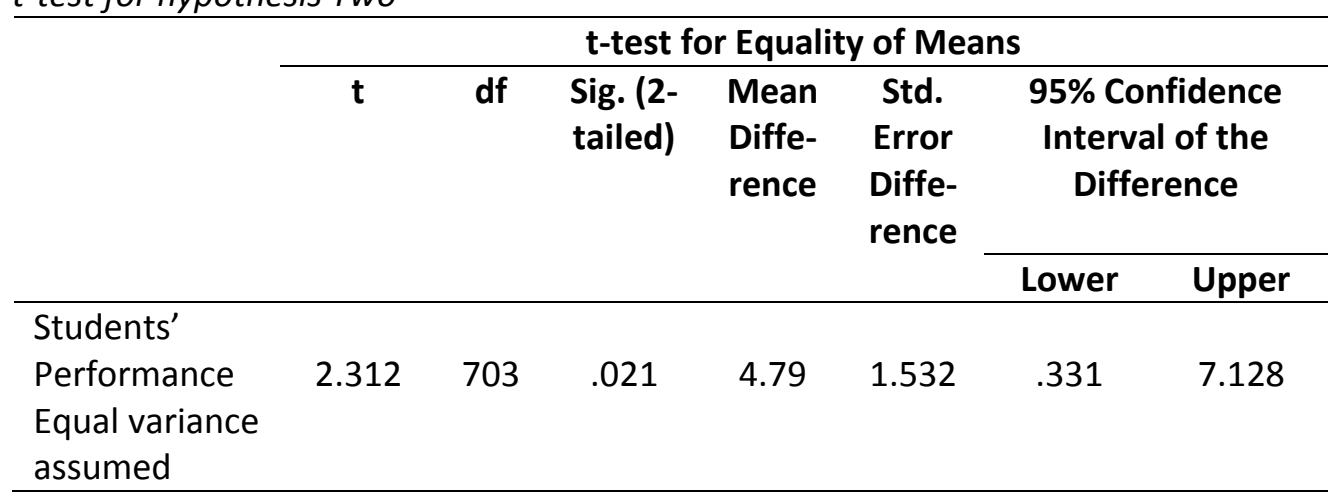


Assumptions $=$ Equal variances assumed

T-Test Calculated (Statistic) $=2.312$

Degree of freedom $=703$

Level of significance $=0.05$

Returned $p$-value $=0.021$

The $t$-test statistics was calculated as 2.312 , at 0.05 significance level, with 703 degrees of freedom, the returned $p$-value of 0.021 was found less than the level of significance $(p<0.05)$. Hence, there is a significant difference between the academic performance of the male and female students of Daaru Da'wah Arabic Institute, Isolo, Lagos in Arabic studies. This indicates that the male students perform significantly better than the females who enroll for Arabic Studies.

\section{5 academic performance.}

Table 11

t-test on performance of male and female students group statistics

\begin{tabular}{ccccc}
\hline Grouping Variables & $\mathbf{N}$ & Mean & $\begin{array}{c}\text { Std. } \\
\text { Deviation }\end{array}$ & $\begin{array}{c}\text { Std. Error } \\
\text { Mean }\end{array}$ \\
\hline Students' Performance & & & & \\
Male & 617 & 8.71 & 12.961 & .739 \\
Female & 83 & 4.79 & .613 & .032 \\
\hline
\end{tabular}

Table 11 shows that the male students performed better with higher mean score of 8.71 in the Arabic Institute than the female students with a lower mean score of 4.79 .

Table 12

t-test for hypothesis Two

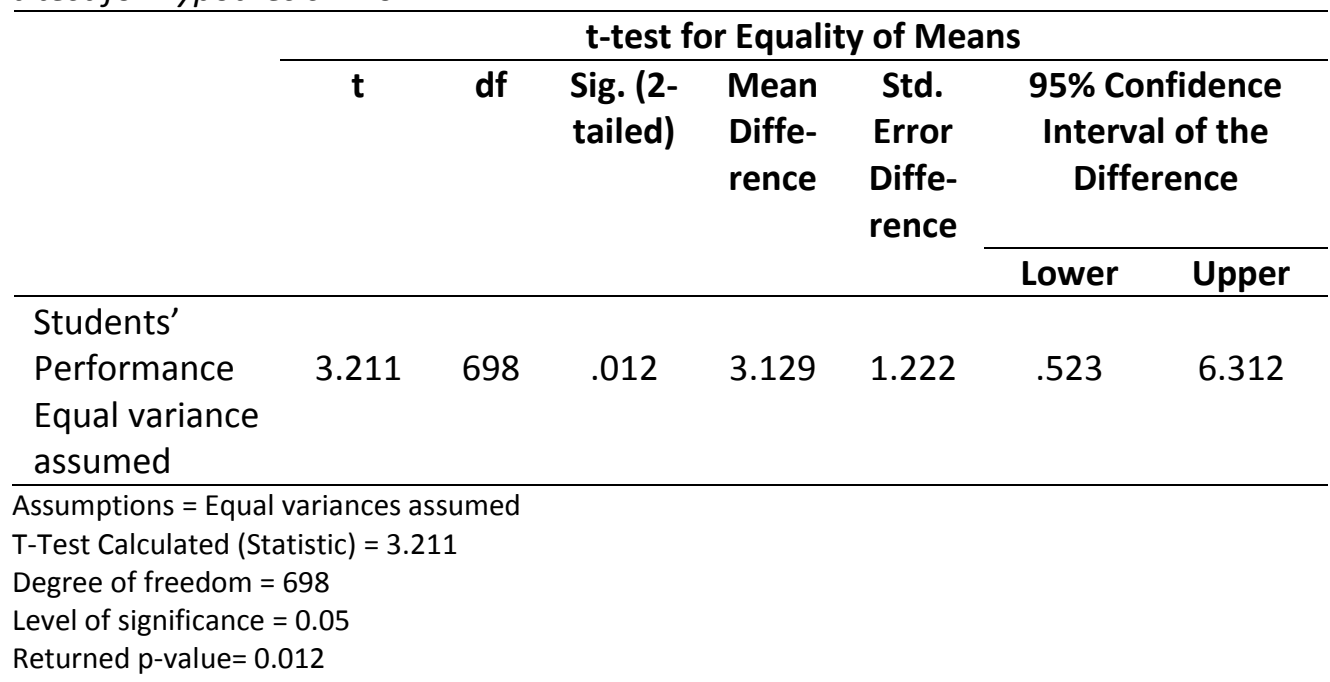

The $t$-test statistics (Table 12) was calculated as 3.211 at 0.05 significance level, with 698 degrees of freedom, the returned $p$-value of 0.012 was found less than the level of significance $(p<0.05)$. There is a significant difference between the 
academic performance of the male and female students of Daaru Da'wah Arabic Institute, Isolo, Lagos in Arabic studies. This indicates that the male students perform significantly better than the females who enroll for Arabic Studies.

\section{6 academic performance.}

Table 13

t-test on performance of male and female students group statistics

\begin{tabular}{ccccc}
\hline Grouping Variables & $\mathbf{N}$ & Mean & $\begin{array}{c}\text { Std. } \\
\text { Deviation }\end{array}$ & $\begin{array}{c}\text { Std. Error } \\
\text { Mean }\end{array}$ \\
\hline Students' Performance & & & & \\
Male & 608 & 7.56 & 14.121 & .978 \\
Female & 92 & 4.12 & .754 & .074 \\
\hline
\end{tabular}

Table 13 shows that the male students performed better with higher mean score of 7.56 in the Arabic Institute than the females with a lower mean score of 4.12.

Table 14

t-test for hypothesis Two

\begin{tabular}{l}
\cline { 3 - 4 } \\
\cline { 3 - 4 }
\end{tabular}




\section{Conclusion}

The male-female enrolment and performance in private formal Arabic schools in Lagos state has been an unexplored area of research and there is a dire need for aggressive research in this area of study. The low level of enrolment for female students in modern formal private schools in Lagos State is unhealthy for balanced education of the teeming womenfolk in Lagos state. There is urgent need to encourage and sensitise the womenfolk on the accruable benefits of embracing Arabic education in the contemporary world and the occupational opportunities which are available to female students of Arabic studies nationally and globally. These include the mass media (both electronic and print), international relations and diplomacy, international trade, commerce and economy, Translation and conference interpreting, international sporting events, and education.

\section{References}

Adetona, L.M. (2017). Dynamics of Islam in Post-Colonial Lagos. $59^{\text {th }}$ Edition of LASU Inaugural Lecture Series, LASU.

Burstall, C. (1975). Factors affecting foreign language learning: A consideration of some resent research findings. Language Teaching and Linguistic Abstracts, 29,132-140.

Gibb, H.A.R., Kramers, J.H., Levi-Provencal, E., Schacht, J., Stern, S.M., Lewis, B., Pellat, Ch., Dumont, C., and Savory, R.M., (Eds (1986). The Encyclopaedia of Islam: Vol. 1. Leiden: E. J. Brill.

Gibb, H. A. R., Lewis, B., van Donzel, E. J., \& Bosworth, C. E. (Eds.). (1986). The Encyclopaedia of Islam: Vol. 1. Leiden: E. J. Brill.

Hitti, P. K. (1972). The Encyclopedia Americana. Chicago: Grolier Incorporated, International Edition.

Li, L.T. (2005). A study on gender differences and influencing factors of high school students in English learning. Portland ME: The George Mitchell Institute.

Mogaji, T. A. (2009). Arabic and the socio-cultural development of Nigeria: An assessment. LASU Journal of Humanities, 6, 160-176.

Nicholson, R.A. (1985). A literary history of the Arabs, Cambridge: Cambridge University Press.

Oderinde, B. B. (2007). English and Arabic in curriculum context: Benefits to the Nigerian Society. $35^{\text {th }}$ Edition of LASU Inaugural Lecture Series. Lagos State University Press.

Qian, W. (2015). A study of the influence of gender differences on English learning of senior high school students. Higher Education of Social Science, 8(6), p. 66-69.

The New Encyclopaedia Britannica. (2003). U.S.A: Encyclopaedia Britannica, Inc., Volume 1, 15th Edition. 